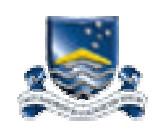

The Australian National University

Demography Program

Research School of Social Sciences

Demographic and Employment Change in Megacities of South-East and East Asia

Gavin W. Jones

Ching-lung Tsay

Bhishna Bajracharya

\title{
Working Papers in Demography
}

No. 80

1999 


\begin{abstract}
This study examines the growth of population and the changing structure of employment in four megacities in South-East and East Asia: Jakarta, Bangkok, Manila and Taipei over the 1980-1990 period. As all these megacities have influenced the population and employment structure in a region extending well beyond their official boundaries, three zones are defined for each megacity: the metropolitan core, and an inner and an outer ring. The metropolitan core in each case is the officially defined metropolitan area. Addition of the two rings approximately doubles the population under consideration, to almost 16 million each in the cases of Jakarta and Manila. The inner ring is the zone of greatest change. It has received net migration from both the metropolitan core and from other parts of the country. Its employment structure has changed the most dramatically, because of location of many factories and other economic enterprises outside the metropolitan boundaries, and also because of the growth of housing estates, many of whose residents commute to work in the city core. The study concludes that studies of demographic and employment change in major metropolitan areas are enriched by the adoption of a zonal perspective.
\end{abstract}




\section{DEMOGRAPHIC AND EMPLOYMENT CHANGE IN MEGACITIES OF SOUTH-EAST AND EAST ASIA}

Gavin W. Jones, Ching-lung Tsay and Bhishna Bajracharya

\section{INTRODUCTION}

The emergence of megacities has been one of the notable features of the last half of the twentieth century. At present, there are 20 cities with populations exceeding 8 million; of these, 11 are in Asia. These cities pose planning issues of a different order from those of smaller cities; although their need for heavy infrastructure investment is clear, they tend to soak up a disproportionate share of development resources, because of their strategic location at the center of power.

The phenomenon of extended metropolitan regions (EMR), interchangeably called mega-urban regions (MUR) has received increasing attention in recent times (Vining, 1986; Ginsburg, Koppel and McGee, 1991; Douglass 1992). Vast urbanized regions surrounding major metropolitan areas clearly exert economic dominance in the countries in which they are located. The regions of most rapid change tend to be those extensive, formerly rural areas surrounding major metropolises or located along transport corridors between major cities, where population is dense and there is an intense interaction between agricultural and nonagricultural activities.

Studies of the extended metropolitan regions in ASEAN reveal that these are major areas of economic growth, fuelled by industrialization, construction and recreation/tourism activities (McGee and Greenberg, 1992). McGee and others argue that these extended metropolitan areas are characterized by high density rural areas with a substantial labour pool, which are attractive for relocating industries. Similarly, improvements in transportation and communication have facilitated greater mobility of people within the region, including commuting 


\section{JONES, TSAY AND BAJRACHARYA}

for quite long distances. The EMRs are also the focus of industrialization and economic growth, creating further concentration of economic activities in the region through the increasing proportion of people engaged in non-agricultural activities, growth of industrial and service activities and development of industrial and housing estates. McGee and Greenburg describe the emergence of EMRs as spatially extended urbanization rather than population concentration covering both the in situ population in EMRs and migrants from other rural areas.

The megacities represent islands of affluence in their respective countries, at least in comparative terms (even in absolute terms, the Bangkok region in Thailand could pass as a NIC among the other fast-growing and affluent economies of the East Asia region). The per capita Gross Regional Product in the Bangkok metropolitan Region was Bt. 42,847 in 1992, ten times greater than in the Northeast (Bt. 4,296) and more than five times greater than in the North or the South (NESDB/UNDP/TDRI, no date, Study Area 3, Table 3). In 1987, the Bangkok Metropolitan Area, with about 10 per cent of Thailand's population, had 59 per cent of Thailand's manufacturing production, 47 per cent of trade, 47 per cent of services and 40 per cent of GDP. In 1985, the Jabotabek region (Jakarta and its near hinterland), with about 9 per cent of Indonesia's population, produced 31 per cent of national industrial product.

The megacities are sites where many of the development dramas facing Asian countries will be played out. For one thing, their share of the populations of these countries is increasing. For another, the issues of poverty, of underemployment and of women's changing opportunities - issues of great concern in current development planning - are of great importance in the megacities. Poverty may not be as prevalent as in many rural areas, but it is extremely visible in the megacities, and presents a more immediate political problem because of its proximity to the centers of decision-making. As for women, their rising share of employment in Asian megacities is striking, as is their predominance in migration patterns to the megacities in many countries of East and Southeast Asia (Hugo, 1993). 
There is no doubt that cities exert an influence on settlement and employment patterns well beyond their borders, and this has become increasingly the case with the development of transportation and communications systems. The "metropolitan turnaround", characterized by a dramatic slowing in the growth of metropolitan areas, often to rates below that of the population as a whole, was much studied in Europe, North America and Japan during the 1970s and 1980s (Vining and Kontuly, 1978; Vining, 1986; Fuguitt, 1985; Inoue, 1980; Tsuya and Kuroda, 1989; Champion, 1989; Hugo and Smailes, 1985). This turnaround was attributed to factors other than merely 'overspill' outside metropolitan boundaries. Nevertheless, it is probably best understood in relation to the concept of extended metropolitan areas. Rather than a 'rustication' of the population through outmigration of population from cities to truly rural areas, the growth of the non-urban population in these countries has tended to occur within the zones of influence of major metropolitan areas, where those settling in "rural" areas can have the best of both worlds - the peace of the countryside and ready access to the facilities of the metropolis. Likewise, most of those showing a preference for rural living want to be within 30 miles of a city of 50,000 or larger (Fuguitt and Brown, 1990).

The turnaround of the 1970s may have been only a temporary phenomenon. In the United States and Japan at least, metropolitan areas have resumed faster growth in the 1980s (Frey and Speare, 1992; Tsuya and Kuroda, 1989). In South-East Asia, a spurious conclusion that a "metropolitan turnaround" was taking place could be drawn from the sharp deceleration of population growth in official municipal areas such as Jakarta and Bangkok during the 1980s. But this would be to ignore the reality of extended metropolitan regions, with much faster population growth on the fringe than in the municipal core.

The major metropolises of South-East Asia clearly influence employment patterns well beyond their boundaries (see, for example, Jones, 1984a; McGee and Greenberg, 1992). Unfortunately, such is the tyranny of administrative boundaries, the employment structure of such extended metropolitan areas is rarely studied. Indeed, such a study requires major efforts to analyse the raw data from censuses, because census offices have proven unsympathetic to 


\section{JONES, TSAY AND BAJRACHARYA}

the idea of presenting data in official tabulations for divisions other than the conventional administrative ones.

The role of extended metropolitan areas is very significant as the key foci of changing employment structure in Asian countries experiencing rapid economic development. For one thing, these extended metropolitan areas provide a significant share of all employment in their respective countries, and in particular a high proportion of employment in manufacturing industry and in modern sector trade and services. For another, the extended metropolitan areas have a particular importance in terms of female employment. Women suffer serious disadvantages in the labour markets of South-East Asia, but with rising educational levels, rapid expansion of some occupations that are traditionally the preserve of women, and perhaps some loosening of rigid sex stereotyping of occupations, the employment picture for women is changing rapidly. Extended metropolitan areas are the target of substantial female migration in most Asian countries, and they were the locus of much of the expansion of female occupational opportunities noted in the region in the 1970-1980 period (Jones, 1984b) and the 1980-1990 period (Singarimbun, 1997, Chapter 2).

\section{ASIAN MEGACITIES: THE IMPORTANCE OF ANALYSIS BY ZONES}

The megacities of Asia are very large indeed. For example, the 1990 populations of the largest megacities of South-East Asia were as follows:

$\begin{array}{ll}\text { Jakarta } & 8.2 \text { million } \\ \text { Bangkok } & 5.9 \text { million } \\ \text { Metro Manila } & 7.9 \text { million }\end{array}$

These populations are for the urban core only, which was taken to be: for Jakarta, the DKI Jakarta; for Bangkok, the Bangkok Metropolitan Area (Bangkok-Thonburi); for Manila, 
Metro Manila. In Jakarta and Manila, this urban core is almost identical in area, but in Bangkok it is more than twice as large:

$\begin{array}{lr}\text { Jakarta } & 664 \text { sq. km. } \\ \text { Bangkok } & 1565 \text { sq. km. } \\ \text { Manila } & 636 \text { sq. km. }\end{array}$

These areas are quite extensive; yet they exclude large built-up areas contiguous to the metropolis. In each case the population of the urban core is approximately doubled when an 'inner ring' of fairly heavily urbanized peripheral areas, plus an outer ring including areas less urbanized but heavily influenced in various ways by the metropolis, is added to it. The population of the extended metropolitan region of Jakarta exceeds the total population of Australia or Sri Lanka, and the extended metropolitan region of Manila is only slightly less populous.

In analyzing population and employment change in the megacities of Asia, it is important to disaggregate this growth spatially, because there are dramatic differences between localities within the far-flung reaches of the megacity. These spatial differences could be analyzed according to a variety of different ways of "breaking up" the area of the megacity. In this study, the starting point was to identify three zones for each of the megacities studied, defining a metropolitan "core" and an inner zone and outer zone outside the core. The inner zone is the zone characterized by metropolitan "overspill", a zone in transition from rural to urban settlement and land use patterns and experiencing very rapid growth in population and employment. The outer zone is also heavily influenced by the growth of the metropolis and likely to achieve "inner zone" characteristics in future, but where rural settlement patterns prevail and agriculture continues to provide a significant share of employment. The inner and outer zone have the rough shape of concentric circles outwards from the core, but with protrusions and irregularities resulting from topographic characteristics, location of former small towns which have grown 


\section{JONES, TSAY AND BAJRACHARYA}

through their linkages with the metropolis, and the influence of transportation routes which enable city influence to penetrate further.

This paper, then, investigates the overall trends in settlement patterns and in employment in selected extended metropolitan regions in South-East and East Asia between 1980 and 1990, differentiating between trends in the metropolitan core and the periphery. The megacities chosen for study are Jakarta, Bangkok, Manila and Taipei. Study of changing settlement patterns focuses on the role of natural increase, population redistribution within the extended metropolitan region, and in-migration from outside the region in the growth of the core and peripheral areas of the extended metropolis. In terms of employment change, emphasis is placed on the comparison of male and female employment trends, the trends for broad age groups, and the differential employment situation of migrants and non-migrants. Particular emphasis will be given to trends in different occupations, using detailed 2 and 3 digit occupational codes. One key issue will be whether women have gained access to a wider range of occupations than previously.

The main data sources were Census tapes for the 1980 and 1990 censuses for the different countries. The areas defined as the urban core, inner zone and outer zone for the purposes of this study are shown in Maps 1 to 4 . The basis on which they were delineated is shown in Appendix Table 1.

Some important hypotheses that require testing include the following (not all of them can be fully explored in the present study):-

(a) Not only is there more rapid employment growth on the periphery than in the core of metropolitan areas, but also the industrial and occupational structure of employment is changing more rapidly in the peripheral areas, particularly the inner zone. 
(b) Migrants are more prominent in the growth of both population and employment in the peripheral than in the core areas, and their employment patterns differ substantially from those of non-migrants.

(c) In extended metropolitan areas, women have gained significant access to a wider range of occupations than was the case in 1980. If this hypothesis is proven to be correct, the source of the gain will be investigated: the extent to which it is due to a shift in occupational structure towards occupations traditionally favouring women, or to gains in women's shares within particular occupations.

(d) Traditional occupations such as domestic service, trishaw pedalling or jeepneybemo driving, and hawking and street vending have declined in importance, more so in the metropolitan core than in the periphery, and been replaced by higher productivity activities (for example, bus driving for trishaw pedalling; employment in supermarkets for street vending).

\section{DATA PROBLEMS}

Although we believe that analysis of population and employment change in the mega-urban regions according to zones is very important, the task of conducting such analysis poses major data problems, which need to be noted at the outset. The first is that official statistical agencies are loath to produce data for areal groupings that cut across administrative divisions. Therefore, piecing together the data for the zones that constitute an extended metropolitan region is a major exercise, and significant gaps remain. The alternative of defining zones in terms of accepted administrative regions, as we did for Bangkok by including only complete changwats in each zone, reduces problems of data availability. On the other hand, it is not fine grained enough, leading to a "second best" outcome in presenting data for functional zones, because many changwats comprise areas with both inner ring and outer ring characteristics. 
There are two major problems relating to the nature of employment data. Firstly, in most censuses and surveys, employment is recorded by place of residence, not by place of work. Thus, for example, much of the employment data presented for the inner zone could refer to jobs that are actually located in the urban core, to which people from the inner zone commute. The second problem is that censuses record only the primary occupation, and this fails to capture the complexity of employment patterns, multiple activities, and household survival strategies that characterize many large urban regions.

A third problem the present study encountered was specific to the Manila data. The Philippines census changed its industrial and occupational classifications between the 1980 and 1990 population censuses. It improved impossible to match the 1980 classifications with those used in 1990. Consequently, these important aspects of employment change between 1980 and 1990 could not be analyzed. In addition, the quality of the employment data for Manila in 1990 left much to be desired; this was reflected in the very large number of cases with occupation not stated (23 per cent in Metro Manila and 14 per cent for the entire EMR).

\section{POPULATION CHANGE IN THE FOUR CITIES}

Over the decade of the 1980s, the populations of the four cities increased substantially. In the core cities, the growth ranged from 22 per cent in Taipei and around 25 per cent in Bangkok and Jakarta to 34 per cent in Manila. But the growth in the periphery was faster in all cases: 27 per cent in Taipei, 29 per cent in Bangkok, 42 per cent in Jakarta, and 39 per cent in Manila. Where population growth in the inner and outer ring can be disaggregated, it is the inner ring that has the most impressive growth: 31 per cent in Taipei, 39 per cent in Bangkok, and 46 per cent in Manila - or a third to a half as fast again as growth in the core. Though precise figures are not available, population growth in the inner ring was even faster in Jakarta. By contrast, the population of the outer ring grew somewhat more slowly than that of the core in the cases of Bangkok and Manila, and much slower in the case of Taipei. What has clearly been happening, then, is that the core has still been receiving net migration, which has kept its growth 
MEGACITIES OF SOUTH-EAST ASIA 9

higher than that of the outer ring, despite the tendency for rates of natural increase to be higher in the outer ring. But the most substantial changes have been in the inner 
Table 1: Population, density and labour force by zones in Extended Metropolitan Regions (EMR), 1980 and 1990

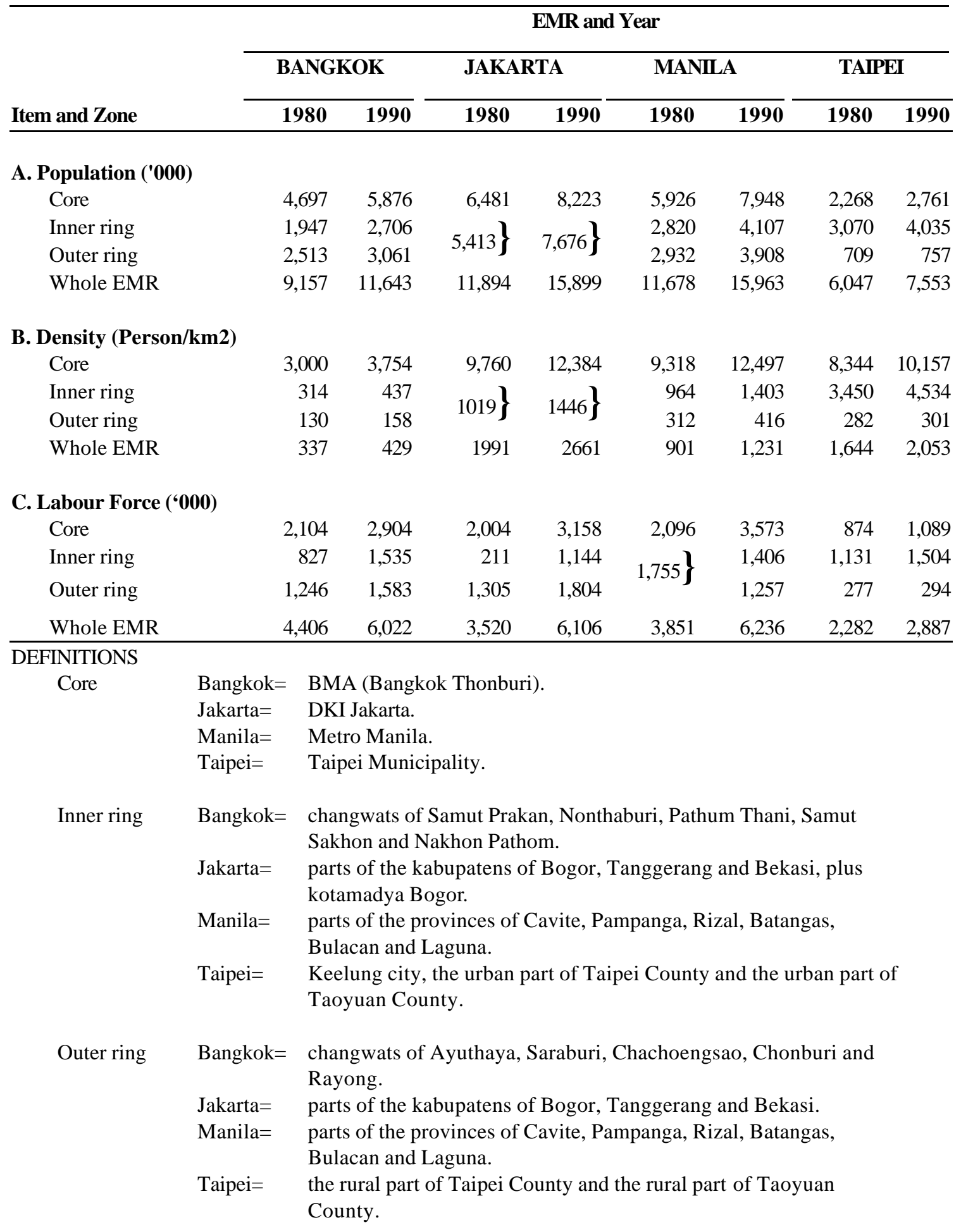


ring, which has received net migration both from the core as part of a suburbanization and industrialization process, and from elsewhere in the country in its role as the part of the extended metropolitan region where housing is affordable and job prospects best.

The density figures in Table 1, along with a reading of Maps 1-4, clarifies a number of differences in the way the extended metropolitan regions have been defined for this study. One noticeable feature is the lower population densities for Bangkok (both the core and the zones) than for the other cities. This is partly the result of generally lower population densities in Bangkok and its surrounding areas than in the case of the other cities ${ }^{1}$; but it is also partly because more extensive areas were used to define both the core and the zones in the case of Bangkok, thus lowering average population densities in these areas. This was necessary because of the decision to adhere to the practices used in Thai planning circles in defining the Bangkok metropolitan region. At the other end of the scale, population densities in the inner core in Taipei are particularly high, reflecting the restricted dimensions of the inner ring as defined for this study.

Tables 2 and 3 show the migration status of the populations of the urban core and of the surrounding zones in Bangkok and Taipei in 1980 and 1990. In the case of Bangkok, the data apply to the population aged 15 and above, because in 1980 there was a large "unknown migration status" group for those aged below 15 .

In the case of Bangkok (Table 2), in both 1980 and 1990, by far the largest migratory movement into the core originated from outside the extended metropolitan region - in fact, from all parts of the country. In 1990, this migration was highly concentrated in the age groups 1524, and to a lesser extent 25-29 (data not shown). By contrast, in the inner zone, almost as much of the net migration originated from Bangkok as from outside the extended metropolitan region, no doubt representing a form of "suburbanization". The age pattern was also different

\footnotetext{
${ }^{1}$ Land use data show that, despite the industrial strength of the provinces included in the inner zone for Bangkok, only a tiny fraction of land is developed (residential, commercial, industrial, government). For
} 


\section{JONES, TSAY AND BAJRACHARYA}

from that of migration to the city proper. Although among migrants to this zone from outside the mega-urban region, the 20-24 year age group had the highest proportion of migrants, migrants from Bangkok itself were much more evenly distributed across age groups, as one would expect in the case of a "suburbanization" movement. (A similar pattern can be observed in migration to the inner zone of the Jakarta EMR - see Jones and Mamas, 1996: 65). In the outer zone, a smaller proportion of the population were migrants and the great majority of these were from outside the extended metropolitan region. ${ }^{2}$

The general pattern of migrant flows in Taiwan in the 1980s was characterized by a net transfer to the North Region, particularly the Taipei metropolis, from the remaining regions. The main reason is that as the economy of Taiwan underwent substantial restructuring toward capital- and knowledge-based type, the emergence of new economic opportunities was heavily concentrated in a few places like Taipei City and Hsinchu City (Taiwan's Silicon Valley). The flows of migrants can be decomposed into primary migration (operationally defined as the migration of those without migration experience, return migration (migration of previous migrants who move back to their home region), and onward migration (migration of previous migrants who move to a place other than their home region). Under this framework, the 1990 census suggests that the primary migration in Taiwan was largely characterized by rural-to-urban moves, the return migration by urban-to-rural moves, and the onward migration by interurban moves. In terms of educational selectivity, the census further reveals that both primary and onward migrations were extremely selective of the best educated as opposed to the slightly negative selectivity of return migration. As for the migration schedule (i.e. age-specific migration rate), primary migrants were in general younger than their return and onward counterparts (Lin 1998).

Inmigrants to the Taipei EMR mostly originated from outside the Taipei EMR (55\% for males and $53 \%$ for females - see Table 3). As for the exchange of population within the extended

example, in Pathum Thani, roughly 3 per cent of total land is built up and the remaining land is used for agriculture or unused for either urban or agricultural purposes (McGee and Greenberg, 1992: 38).

${ }^{2}$ There is an anomaly in the outer zone figures for males in 1990, with the proportion of migrants in the case of males greatly exceeding the proportion for females. This results from the cluster sampling techniques 
area, contiguity appears to be the most important factor. The data clearly show that the largest source of exchange for the core, the inner ring and the outer ring is the inner ring, the core, and the inner ring, respectively. The second column of Table 3, however, reveals that the inner ring had the lowest share of population who did not move in 1985-90, indicating that inmigrants were in favor of targeting the inner ring of the extended area. In terms of gender, female inmigrants slightly outnumbered their male counterparts. The core tended to attract female inmigrants as opposed to the inner and outer rings that were selective of male inmigrants.

Migration can lead to major changes in certain characteristics of the population. In the case of Jakarta's inner ring, there has been a remarkable improvement in the educational levels of the population between 1980 and 1990. The educational attainment, both of the population moving to the ring from Jakarta's core and of the migrants from elsewhere in Indonesia, was considerably higher than that of the local-born population of the inner ring - partly, of course, because migrants were disproportionately young, and young people have higher average educational attainment, but also because for any given age group, education of migrants was higher than that of non-migrants. The educational levels of the local-born reflected the relatively low education of the mainly rural population of this region of West Java. Thus over the course of the 1980s, the proportion of the employed population of Jakarta's inner ring who had at least completed lower secondary education increased from 17 per cent to 49 per cent (Jones and Mamas, 1996, Table 7).

used, which resulted in a large military camp in Cholburi province giving an artificially high weighting to male migrants (personal communication with National Statistics Office). CHECK 
Table 2

Migration status of population aged 15+ in Bangkok Metropolitan Region by zones, 1980 and 1990 (\% distribution)

\begin{tabular}{|c|c|c|c|c|c|c|}
\hline \multirow[b]{2}{*}{$\frac{\text { Current residence }}{1980}$} & \multirow{2}{*}{$\begin{array}{l}\text { Did not } \\
\text { migrate }\end{array}$} & \multicolumn{4}{|c|}{ Migrated from } & \multirow[b]{2}{*}{ Unknown } \\
\hline & & Bangkok & Inner zone & Outer Zone & Elsewhere & \\
\hline
\end{tabular}

\section{MALES}

Bangkok $^{+}$

Inner Zone

Outer Zone

\section{FEMALES}

Bangkok

Inner Zone

Outer Zone

$\underline{1990}$

\section{MALES}

Bangkok $^{+}$

Inner Zone

Outer Zone

\section{FEMALES}

Bangkok $^{+}$

Inner Zone

Outer Zone

82.9

85.7

94.1

83.4

84.1

83.9

$*$
3.2
1.1

0.8

1.0

0.8

6.8

10.8

100

86.1

1.1

0.3

$*$

4.9

5.0

100

\section{.}

80.6

86.5

92.7

$*$
3.2
0.6

0.9
$*$
0.3

1.2

0.8

7.1
4.7
3.1

10.2

4.9

3.3

100

100

100

\footnotetext{
${ }^{+}$Bangkok Metropolitan Area

*Not applicable

Source: Calculated from 1\% sample tapes of the 1980 and 1990 Population Censuses provided by the National Statistical Office, Bangkok.
} 


\begin{tabular}{|c|c|c|c|c|c|c|c|c|}
\hline \multicolumn{9}{|c|}{ Table 3: Total Labor Force by Sex and Migrant Status, Taipei Extended Metropolitan Region, 1990.} \\
\hline & & & & & & & & \\
\hline & & & & \multicolumn{5}{|c|}{ Migrants of $1985-90$ by Place of Orgin (\%) } \\
\hline & Total & $\%$ of & \multirow{3}{*}{$\begin{array}{c}\text { Total } \\
\text { Number }\end{array}$} & Taipei & Taipei Pref. + & Taoyuan & Other & Other \\
\hline & Labor & Non- & & City & Keelung City & Prof. & Cities & Prefectures \\
\hline & Force & Migrants & & (Core) & (Inner Ring) & (Outer Ring) & & \\
\hline & & & & & & & & \\
\hline \multicolumn{9}{|c|}{$\underline{\text { Male }}$} \\
\hline & & & & & & & & \\
\hline Taipei EMR & $2,684,742$ & 88.58 & 306,538 & 22.00 & 18.22 & 5.24 & 10.01 & 44.53 \\
\hline Taipei City & 995,896 & 89.94 & 100,226 & & 34.84 & 6.68 & 14.51 & 43.98 \\
\hline \multicolumn{9}{|l|}{ (Core) } \\
\hline Taipei Pref. + & $1,411,904$ & 86.64 & 151,168 & 39.21 & 4.36 & 6.20 & 7.16 & 43.07 \\
\hline \multicolumn{9}{|l|}{ Keelung City } \\
\hline \multicolumn{9}{|l|}{ (Inner Ring) } \\
\hline Taoyuan Pref. & 276,942 & 93.59 & 55,144 & 14.81 & 25.99 & & 9.67 & 49.53 \\
\hline \multicolumn{9}{|l|}{ (Outer Ring) } \\
\hline & & & & & & & & \\
\hline \multicolumn{9}{|c|}{ Female } \\
\hline & & & & & & & & \\
\hline Taipei EMR & $2,664,075$ & 87.97 & 320,512 & 21.25 & 19.35 & 5.93 & 9.82 & 43.64 \\
\hline Taipei City & $1,030,955$ & 88.76 & 115,870 & & 36.36 & 7.39 & 14.28 & 41.97 \\
\hline \multicolumn{9}{|l|}{ (Core) } \\
\hline Taipei Pref. + & $1,383,039$ & 86.54 & 158,667 & 39.05 & 4.94 & 6.58 & 7.09 & 42.33 \\
\hline \multicolumn{9}{|l|}{ Keelung City } \\
\hline \multicolumn{9}{|l|}{ (Inner Ring) } \\
\hline Taoyuan Pref. & 250,081 & 92.63 & 45,975 & 13.39 & 26.22 & & 8.01 & 52.38 \\
\hline (Outer Ring) & & & & & & & & \\
\hline $\begin{array}{l}\text { Source: } 1990 \text { Tai } \\
\text { Population Cens }\end{array}$ & & & & & & & & \\
\hline
\end{tabular}




\section{EMPLOYMENT CHANGES IN EXTENDED METROPOLITAN REGIONS}

All the extended metropolitan regions are going through major growth in employment, although their growth rates differ. Tables 4, 5 and 6 show the changes in levels of employment in Taipei, Jakarta and Bangkok respectively between 1980 and 1990. Jakarta EMR (Jabotabek) shows the fastest rate of employment change, followed by Bangkok EMR and then Taipei EMR: a 69 per cent increase in Jakarta, compared with 45 per cent in Bangkok and only 26 percent in Taipei. The largest percent increase in employment has taken place in the inner rings in all cases, although the growth in Jabotabek's inner ring (425 percent) is much higher than Bangkok's (55 per cent) and Taipei's (32 percent). This would be partly due to the overall higher rate of growth of the labour force, and of employment, in Indonesia and its faster pace of urbanization at this stage. But more important is undoubtedly the way the inner ring was defined for Jakarta, a rapid pace of population growth being a key criterion, whereas the inner ring for Bangkok was defined in purely administrative terms, and included areas which remained heavily rural.

Taipei's inner ring had already experienced considerable growth and industrialization before 1980, in contrast to the inner rings of both Jabotabek and Bangkok. Taipei's and Bangkok's inner rings were already providing employment to 1 million people in 1980 while Jabotabek's inner ring was providing employment to only 207 thousand people at that time (It should be noted here that employment growth is according to the residence of the workers, not necessarily their place of work, therefore the census data does not provide information on changing workplace locations).

Another important trend emerges when the data on employment change is broken down by sex. Changes in women's employment are much more substantial than those for men in all zones within the EMRs. For example, between 1980 and 1990 in Jabotabek, women's total employment increased by 94 percent as compared to 61 percent for men. Similarly, Taipei 
EMR's total employment grew by 64 percent for women, whereas the corresponding figure for men was only 12 percent. The inner rings of the EMRs again

Table 4. Employment Change (in 000s) in Taipei EMR by Sex, 1980-1990

\begin{tabular}{lrrrr}
\hline Zone & 1980 & 1990 & $\begin{array}{r}\text { Absolute } \\
\text { Increase }\end{array}$ & $\begin{array}{r}\text { Percent } \\
\text { Increase }\end{array}$ \\
\hline CORE AREA & 839 & 1,048 & 209 & 24.9 \\
Total & 593 & 645 & 52 & 8.8 \\
Male & 246 & 403 & 157 & 63.8 \\
Female & & & & \\
INNER RING & 1,087 & 1,438 & 351 & 32.2 \\
Total & 801 & 948 & 147 & 18.3 \\
Male & 286 & 490 & 204 & 71.3 \\
Female & & & & \\
OUTER RING & 266 & 285 & 19 & 7.1 \\
Total & 199 & 196 & -3 & -1.5 \\
Male & 67 & 89 & 22 & 32.8 \\
Female & & & & \\
TAIPEI EMR & 2,192 & 2,771 & 579 & 26.4 \\
Total & 1,593 & 1,789 & 196 & 12.3 \\
Male & 599 & 982 & 383 & 63.9 \\
Female & & & & \\
\hline
\end{tabular}

Table 5. Employment Change (in 000s) in Jabotabek by Sex, 1980-1990

\begin{tabular}{lrrrr}
\hline Zone & 1980 & 1990 & $\begin{array}{r}\text { Absolute } \\
\text { Increase }\end{array}$ & $\begin{array}{r}\text { Percent } \\
\text { Increase }\end{array}$ \\
\hline CORE AREA & 1,928 & 2,932 & 1,004 & 52.0 \\
Total & 1,426 & 2,038 & 612 & 42.9 \\
Male & 502 & 894 & 392 & 78.1 \\
Female & & & & \\
INNER RING & 207 & 1,088 & 881 & 425 \\
Total & 170 & 791 & 621 & 365 \\
Male & 37 & 296 & 259 & 700 \\
Female & & & & \\
OUTER RING & 1,280 & 1,735 & 455 & 35.5 \\
Total & 1,001 & 1,340 & 339 & 33.8 \\
Male & 278 & 395 & 117 & 42.1 \\
Female & & & & \\
JABOTABEK & 3,414 & 5,755 & 2,341 & 68.6 \\
Total & & &
\end{tabular}


18 JONES, TSAY AND BAJRACHARYA

\begin{tabular}{lrrrr} 
Male & 2,597 & 4,169 & 1,572 & 60.5 \\
Female & 817 & 1,585 & 768 & 94.0 \\
\hline
\end{tabular}


Table 6. Employment Change (in 000s) in Bangkok EMR by Sex, 1980-1990

\begin{tabular}{lrrrr}
\hline Zone & 1980 & 1990 & $\begin{array}{r}\text { Absolute } \\
\text { Increase }\end{array}$ & $\begin{array}{r}\text { Percent } \\
\text { Increase }\end{array}$ \\
\hline CORE AREA & 2,014 & 2,967 & 953 & 47.3 \\
Total & 1,146 & 1,615 & 469 & 40.9 \\
Male & 868 & 1,352 & 484 & 55.8 \\
Female & & & & \\
INNER RING & 961 & 1,493 & 532 & 55.4 \\
Total & 503 & 783 & 280 & 55.7 \\
Male & 458 & 710 & 252 & 55.0 \\
Female & & & & \\
OUTER RING & 1,283 & 1,703 & 420 & 32.7 \\
Total & 668 & 892 & 224 & 33.5 \\
Male & 615 & 811 & 196 & 31.9 \\
Female & & & & \\
BANGKOK EMR & 4,258 & 6,164 & 1,906 & 44.8 \\
Total & 2,317 & 3,290 & 973 & 42.0 \\
Male & 1,941 & 2,873 & 932 & 48.0 \\
Female & & &
\end{tabular}

exhibited the largest percentage growth in women's employment, reflecting their rapid economic transformation.

\section{CHANGES IN INDUSTRIAL STRUCTURE}

Growth in total employment in the EMRs was accompanied by changes in the distribution of different industries and occupations within the three zones. Data on industrial structures of Taipei EMR and Jabotabek for 1980 and 1990 are given in Table 7, and that for Bangkok EMR and Manila EMR in Table 8. Between 1980 and 1990, the share of manufacturing in Jabotabek increased by 7 percent (from 15 percent to 22 percent). This translates into 759,000 new manufacturing jobs within Jabotabek in the ten year period. This increase in manufacturing occurred in all three zones, particularly in the inner zone where the share of manufacturing actually increased from 15 percent to 27 percent, almost a doubling in share over this period. There was a general decline in the share of agriculture-related workers, reflecting a shift from an 


\section{JONES, TSAY AND BAJRACHARYA}

agricultural towards an industrial economy. The share of the finance and insurance sector has also increased in DKI Jakarta, which shows its growing importance as the financial center of the country. The share of services fell everywhere except the inner ring.

By contrast, in Taipei, the share of manufacturing was already high in 1980, and there was no substantial change in this share between 1980 and 1990. As in Jakarta, the finance sector's share rose substantially, and the share of services fell.

Bangkok, and to a lesser extent Manila, provide a contrast with the other cities in that agriculture continues to provide a much higher proportion of employment in their inner and outer rings than is the case in Jakarta or Taipei. This reflects two things: the wide geographic extent of the areas chosen to represent their inner and outer rings, and the tendency to record very high labour force participation rates for farmers' wives, especially in Thailand. With agriculture providing 64 per cent of employment in Bangkok's outer ring in 1980, it is clear that employment in this area was little affected by Bangkok's proximity. Even in the inner ring, agriculture was providing almost half of employment. Nevertheless, by 1990, the share of agriculture had declined considerably, particularly in the inner ring (to 27 per cent), and it can be expected that by the time of the year 2000 census, Bangkok's inner and outer rings will have come to resemble more closely the employment patterns already displayed in 1990 by those in Jakarta and Taipei.

The measure of index of dissimilarity (ID) has been used in this paper to summarize the changes in industrial and occupational structure over time and the difference between zones at given times. The index of dissimilarity shows the extent of difference between two percentage distributions. Its value can range from 0 to 100 , indicating the proportion of one distribution that would have to be reallocated to have a similar distribution to the other one. When using this index to measure the changes in industrial structure (applied using the one-digit codes for industry), a value of 0 would mean no change in distribution between the two census periods, while the value of 100 would be a complete change in distribution. In the cases of both Jabotabek and Bangkok, the value of the index of dissimilarity was largest in the inner ring (17.6 
MEGACITIES OF SOUTH-EAST ASIA 21

in Jakarta, 18.0 in Bangkok) as compared to that in the core (DKI Jakarta: 11.7, Bangkok 8.6)

or

outer ring

$(11.8$

in Jakarta,

14.0

in 
Table 7. Taipei and Jabotabek: Employed Persons by Industry and Zone, 1980 and 1990 (\% distribution)

\begin{tabular}{|c|c|c|c|c|c|c|c|c|}
\hline \multirow[t]{3}{*}{ Industry } & \multicolumn{4}{|c|}{ Taipei EMR } & \multicolumn{4}{|c|}{ Jabotabek } \\
\hline & Core & Inner & Outer & Total & DKI & Inner & Outer & Total \\
\hline & & Ring & Ring & EMR & & Ring & Ring & EMR \\
\hline \multicolumn{9}{|l|}{1980} \\
\hline Agriculture, forestry & 1.9 & 5.3 & 23.9 & 6.2 & 1.9 & 18.4 & 30.9 & 13.7 \\
\hline Mining and quarrying & 0.3 & 0.6 & 3.8 & 0.9 & 0.7 & 1.3 & 1.3 & 1.0 \\
\hline Manufacturing & 23.9 & 37.3 & 32.7 & 31.7 & 14.9 & 14.6 & 15.8 & 15.2 \\
\hline Electricity, gas, water & 0.9 & 0.7 & 0.8 & 0.8 & 0.6 & 0.4 & 0.2 & 0.4 \\
\hline Construction & 7.1 & 7.9 & 6.7 & 7.5 & 6.7 & 6.7 & 4.6 & 5.9 \\
\hline Trade & 24.0 & 15.0 & 8.1 & 17.5 & 24.6 & 25.5 & 22.1 & 23.7 \\
\hline Transportation & 8.5 & 8.4 & 4.4 & 8.0 & 8.3 & 5.7 & 4.4 & 6.7 \\
\hline Finance & 5.3 & 2.5 & 1.0 & 3.4 & 3.4 & 1.7 & 0.9 & 2.4 \\
\hline Services & 28.0 & 22.3 & 18.5 & 24.0 & 38.8 & 25.8 & 19.9 & 30.9 \\
\hline Total & 100 & 100 & 100 & 100 & 100 & 100 & 100 & 100 \\
\hline $\mathrm{N}(000 \mathrm{~s})$ & 839 & 1,150 & 266 & 2,255 & 1,928 & 207 & 1,280 & 3,414 \\
\hline \multicolumn{9}{|l|}{1990} \\
\hline Agriculture, forestry & 1.4 & 3.6 & 22.2 & 4.7 & 1.1 & 5.5 & 23.5 & 8.6 \\
\hline Mining and quarrying & 0.1 & 0.1 & 0.6 & 0.2 & 0.6 & 1.2 & 1.6 & 1.1 \\
\hline Manufacturing & 22.6 & 37.9 & 35.9 & 31.9 & 20.6 & 26.6 & 22.3 & 22.2 \\
\hline Electricity, gas, water & 0.8 & 0.6 & 0.9 & 0.7 & 0.6 & 0.9 & 0.3 & 0.6 \\
\hline Construction & 5.8 & 8.7 & 8.1 & 7.5 & 6.4 & 7.5 & 5.9 & 6.4 \\
\hline Trade & 28.3 & 18.9 & 11.7 & 21.7 & 26.7 & 20.8 & 21.8 & 24.1 \\
\hline Transportation & 8.1 & 7.9 & 4.6 & 7.6 & 7.4 & 7.6 & 7.2 & 7.4 \\
\hline Finance & 9.8 & 5.2 & 2.4 & 6.7 & 7.3 & 3.2 & 1.7 & 4.8 \\
\hline Services & 23.1 & 17.1 & 13.6 & 19.0 & 29.2 & 26.6 & 15.7 & 24.7 \\
\hline Total & 100 & 100 & 100 & 100 & 100 & 100 & 100 & 100 \\
\hline $\mathrm{N}(000 \mathrm{~s})$ & 1048 & 1,446 & 283 & 2,777 & 2,932 & 1,088 & 1,735 & 5,755 \\
\hline
\end{tabular}


Table 8. Bangkok and Manila EMRs: Employed Persons by Industry and Zone, 1980 and 1990 (\% distribution)

\begin{tabular}{|c|c|c|c|c|c|c|c|c|}
\hline \multirow[t]{3}{*}{ Industry } & \multicolumn{4}{|c|}{ Bangkok EMR } & \multicolumn{4}{|c|}{ Manila EMR } \\
\hline & Core & Inner & Outer & Total & Core & Inner & Outer & Total \\
\hline & & Ring & Ring & EMR & & Ring & Ring & EMR \\
\hline \multicolumn{9}{|l|}{1980} \\
\hline Agriculture, forestry & 5.5 & 45.1 & 63.9 & 32.1 & & & & \\
\hline Mining and quarrying & 0.1 & 0.7 & 0.5 & 0.4 & & & & \\
\hline Manufacturing & 22.8 & 21.6 & 9.6 & 18.5 & & & & \\
\hline Electricity, gas, water & 1.2 & 0.9 & 0.3 & 0.9 & & & & \\
\hline Construction & 5.7 & 3.7 & 2.8 & 4.4 & & & & \\
\hline Trade & 23.8 & 11.0 & 9.8 & 16.7 & & & & \\
\hline Transportation & 7.5 & 3.9 & 2.6 & 5.2 & & & & \\
\hline Finance & 3.6 & 0.8 & 0.4 & 2.0 & & & & \\
\hline Services & 29.7 & 12.4 & 10.2 & 19.9 & & & & \\
\hline Total & 100 & 100 & 100 & 100 & & & & \\
\hline $\mathrm{N}(000 \mathrm{~s})$ & 2014 & 961 & 1,283 & 4,258 & & & & \\
\hline \multicolumn{9}{|l|}{1990} \\
\hline Agriculture, forestry & 2.6 & 27.4 & 50.0 & 21.9 & 1.7 & 12.0 & 33.1 & 11.9 \\
\hline Mining and quarrying & 0.1 & 0.3 & 0.4 & 0.2 & 0.1 & 0.3 & 0.2 & 0.1 \\
\hline Manufacturing & 26.3 & 29.4 & 13.2 & 23.4 & 21.8 & 22.9 & 14.5 & 20.3 \\
\hline Electricity, gas, water & 1.0 & 1.1 & 0.4 & 0.9 & 0.6 & 0.7 & 0.5 & 0.6 \\
\hline Construction & 7.0 & 4.1 & 4.7 & 5.6 & 7.7 & 11.3 & 9.1 & 9.0 \\
\hline Trade & 27.2 & 14.4 & 12.8 & 20.1 & 16.8 & 14.7 & 13.3 & 15.4 \\
\hline Transportation & 6.9 & 4.3 & 2.6 & 5.0 & 10.6 & 10.8 & 8.2 & 10.1 \\
\hline Finance & 4.1 & 1.3 & 0.5 & 2.4 & 8.7 & 4.6 & 2.7 & 6.2 \\
\hline Services & 24.8 & 17.7 & 15.4 & 20.5 & 31.9 & 22.8 & 18.3 & 26.4 \\
\hline Total & 100 & 100 & 100 & 100 & 100 & 100 & 100 & 100 \\
\hline $\mathrm{N}(000 \mathrm{~s})$ & 2967 & 1,468 & 1,703 & 6,164 & 2,481 & 1,298 & 1,164 & 4,943 \\
\hline
\end{tabular}

(For both Bangkok and Manila, "activities not adequately defined or not stated" were pro-rated across industry groups) 
Bangkok, indicating that the greatest change in the industrial structure was in the inner ring (Table 9). By contrast, in Taipei, it was in the outer ring that the change in industrial structure was greatest. This is probably because the outer limits of the inner ring in the case of Taipei are a relatively short distance from the core, which means that the inner ring already resembled the core in industrial structure, and the main action in changing industrial structure was forced out to the outer ring.

Table 9: Index of Dissimilarity (ID) between Industrial Structures of EMRs in 1980 and 1990.

\begin{tabular}{lrcc}
\hline & $\begin{array}{c}\text { Taipei } \\
\text { EMR }\end{array}$ & Jabotabek & $\begin{array}{l}\text { Bangkok } \\
\text { EMR }\end{array}$ \\
\hline Core & 8.7 & 11.7 & 8.6 \\
Inner Ring & 7.8 & 17.6 & 18.0 \\
Outer Ring & 17.7 & 11.8 & 14.0 \\
EMR & 7.6 & 11.3 & 10.5 \\
\hline
\end{tabular}

(Indicator of Change in Industrial Structure of Different Zones between 1980 and 1990)

The changes in the distribution of employment by industry in Taipei EMR are in many ways different from those in Jabotabek and Bangkok. First, there is an indication of a general shift from an industrial to a post-industrial economy, with growing importance of sectors such as finance and commerce in the EMR. Employment in manufacturing was not growing as rapidly as in Jabotabek or Bangkok - in fact it was slowing down. The share of manufacturing in total employment of women was declining in all zones. Historically, Taiwan experienced manufacturing growth in the 1960s and 1970s with the new international division of labour, which resulted in surging domestic and multinational investments in industries in Taiwan. But in recent years, as a result of economic growth and general competition from SE Asian countries to attract industries through cheap labour, Taiwan is diversifying its economy to areas such as finance and commerce. 
In all three cities, the importance of service industries in the core declined substantially between 1980 and 1990. In Jakarta, the decline in share was quite drastic - from 39 per cent to 29 per cent. But the cities differed in the extent of decline in service industries in their EMR as a whole in Taipei, service industries suffered a decline in share in all zones, and in Jakarta, in all except the inner ring. However, in Bangkok, the decline in the core was offset by increases in the inner and outer ring, the net effect for the EMR as a whole being a slight rise in the share of the service sector. Meaningful interpretation of the trends would require a disaggregation of the components of the service sector, as this is a heterogeneous grouping of activities.

\section{CHANGES IN OCCUPATIONAL STRUCTURE}

Table 10 shows the distribution of employment by occupation for people living in different zones within Jabotabek and Taipei EMR in 1980 and 1990. Tables 11 and 12 show data on occupational structure of Bangkok and Manila EMRs respectively. Examining the data crosssectionally first, there is a clear gradation from the core to the outer ring. The core has a high proportion of professional, managerial and clerical workers among total workers (26\% in Jakarta in 1990, 32\% in Bangkok in the same year), whereas the inner ring has substantially less and the outer ring still less (less than 10\% in Jakarta, just over 10\% in Bangkok). A similar coreto-outer ring gradation applies to the proportion of sales and service workers (except, strangely, in Jakarta, where sales workers are almost as well represented in the rings as they are in the core). By contrast, in all cities the proportion of workers in agriculture rises with distance from the metropolitan core.

For Jabotabek, there has been a general increase in the share of employment held by production workers, followed closely by clerical workers. During the intercensal period, employment in production occupations increased from 170,000 to 421,000 in Jabotabek. This has been balanced by a decline in the share of employment in farming occupations. These changes have been most significant in the inner and outer rings, while there has not been much change in occupational structure in the core (DKI Jakarta). The index of dissimilarity between 


\section{JONES, TSAY AND BAJRACHARYA}

occupational structures of 1980 and 1990 for inner and outer zones were found to be 19.5 and 9.6 respectively but the corresponding figure for DKI Jakarta 
Table 10. Taipei EMR and Jabotabek: Employed Persons by Occupation and Zone, 1980 and 1990 (\% distribution)

\begin{tabular}{lrrrrrrrr}
\hline Occupation & \multicolumn{1}{c}{ Taipei EMR } & \multicolumn{7}{l}{ Jabotabek } \\
& Core & Inner & Outer & Total & DKI & Inner & Outer & Total \\
& & Ring & Ring & EMR & & Ring & Ring & EMR \\
1980 & & & & & & & & \\
Professional \& tech. & 11.6 & 7.3 & 4.0 & 8.6 & 6.8 & 3.8 & 3.0 & 5.2 \\
Admin \& mangerial & 3.8 & 2.0 & 0.5 & 2.5 & 1.0 & 0.2 & 0.1 & 0.6 \\
Clerical & 27.5 & 17.9 & 8.7 & 20.5 & 15.2 & 5.8 & 4.0 & 10.4 \\
Sales & 16.9 & 11.6 & 6.4 & 13.0 & 23.1 & 26.1 & 22.7 & 23.1 \\
Service & 10.2 & 7.8 & 6.0 & 8.5 & 18.1 & 8.9 & 6.2 & 13.1 \\
Farming & 1.9 & 5.3 & 26.1 & 6.5 & 2.0 & 19.1 & 31.4 & 14.1 \\
Production & 28.1 & 48.1 & 48.2 & 40.4 & 33.9 & 36.1 & 32.5 & 33.5 \\
& & & & & & & & \\
Total & 100 & 100 & 100 & 100 & 100 & 100 & 100 & 100 \\
N (000s) & 839 & 1,087 & 266 & 2,192 & 1,928 & 207 & 1,280 & 3,414 \\
& & & & & & & & \\
1990 & & & & & & & & \\
Professional \& tech. & 14.0 & 8.9 & 6.0 & 10.5 & 6.7 & 6.0 & 3.3 & 5.6 \\
Admin \& mangerial & 3.1 & 1.3 & 0.6 & 1.9 & 1.6 & 0.6 & 0.3 & 1.0 \\
Clerical & 33.3 & 21.9 & 13.0 & 25.3 & 17.2 & 14.0 & 5.9 & 13.2 \\
Sales & 20.1 & 14.3 & 8.7 & 15.9 & 22.8 & 20.1 & 21.4 & 21.9 \\
Service & 9.7 & 8.9 & 7.9 & 9.1 & 16.4 & 9.9 & 5.8 & 12.0 \\
Farming & 1.4 & 3.6 & 22.1 & 4.6 & 1.1 & 5.6 & 23.6 & 8.7 \\
Production & 18.5 & 41.1 & 41.6 & 32.6 & 34.1 & 43.7 & 39.7 & 37.6 \\
& & & & & & & & \\
Total & 100 & 100 & 100 & 100 & 100 & 100 & 100 & 100 \\
N (000s) & 1048 & 1,446 & 283 & 2,778 & 2,932 & 1,088 & 1,735 & 5,755 \\
\hline & & & & & & & & \\
\hline
\end{tabular}


Table 11: Bangkok: Employed Persons by Occupation and Zone, 1980 and 1990 (\% distribution)

\begin{tabular}{|c|c|c|c|c|}
\hline & $\begin{array}{l}\text { Core } \\
\text { BMA }\end{array}$ & Inner Ring & $\begin{array}{r}\text { Outer } \\
\text { Ring }\end{array}$ & $\begin{array}{l}\text { Total } \\
\text { EMR }\end{array}$ \\
\hline \multicolumn{5}{|l|}{1980} \\
\hline Professional & 8.1 & 4.4 & 3.7 & 6.1 \\
\hline Administrative & 8.1 & 3.0 & 3.2 & 5.6 \\
\hline Clerical & 10.2 & 3.8 & 1.9 & 6.5 \\
\hline Sales & 21.6 & 11.5 & 13.2 & 17.0 \\
\hline Service & 12.7 & 4.9 & 4.6 & 8.7 \\
\hline Agriculture & 4.4 & 38.8 & 45.7 & 23.3 \\
\hline Transp. \& crafts (Production) & 34.2 & 33.7 & 27.6 & 32.3 \\
\hline Not Classifiable & 0.8 & 0.2 & 0.2 & 0.5 \\
\hline Total & 100 & 100 & 100 & 100 \\
\hline $\mathrm{N}(000 \mathrm{~s})$ & 1,937 & 889 & 1,023 & 3,849 \\
\hline \multicolumn{5}{|l|}{1990} \\
\hline Professional & 15.1 & 6.8 & 4.9 & 10.2 \\
\hline Administrative & 5.7 & 2.6 & 2.8 & 4.1 \\
\hline Clerical & 11.1 & 6.9 & 2.8 & 7.5 \\
\hline Sales & 19.8 & 12.8 & 12.3 & 16.0 \\
\hline Service & 10.0 & 4.8 & 4.7 & 7.4 \\
\hline Agriculture & 2.7 & 26.6 & 41.9 & 19.0 \\
\hline Transp. \& crafts (product.) & 35.2 & 38.5 & 30.4 & 35.0 \\
\hline Not Classifiable & 0.5 & 1.1 & 0.3 & 0.6 \\
\hline Total & 100 & 100 & 100 & 100 \\
\hline $\mathrm{N}(000 \mathrm{~s})$ & 2,901 & 1,534 & 1,583 & 6,017 \\
\hline
\end{tabular}

Source: Calculated from 1980 Population Census, changwat volumes, Table 23; 1990

Population Census, changwat volumes, Table 21. 
Table 12: Manila EMR: Employed Persons by Occupation and Zone 1990 (\%

\section{distribution)}

\begin{tabular}{lrrrr}
\hline & $\begin{array}{l}\text { Metro } \\
\text { Manila }\end{array}$ & Inner Ring & $\begin{array}{r}\text { Outer } \\
\text { Ring }\end{array}$ & $\begin{array}{r}\text { Total } \\
\text { EMR }\end{array}$ \\
& & & & \\
\hline $\mathbf{1 9 9 0}$ & & & & \\
Officials of govt & 7.8 & 6.8 & 3.7 & 6.7 \\
Professionals & 8.3 & 6.8 & 5.3 & 7.3 \\
Technicians \& Asso. Prof.. & 4.4 & 2.7 & 1.7 & 3.5 \\
Clerks & 6.7 & 6.5 & 5.3 & 6.4 \\
Service \& shop market sales & 7.4 & 6.5 & 5.8 & 6.8 \\
Farmers, Forestry etc. & 0.9 & 9.3 & 26.8 & 8.4 \\
Craft and related workers & 13.9 & 23.1 & 17.7 & 16.9 \\
Plant and machine operators & 7.6 & 12.5 & 8.9 & 9.1 \\
Elementary occupations & 18.8 & 18.9 & 19 & 18.9 \\
Occup. N.e.c. & 1.3 & 3.1 & 2.4 & 2.2 \\
Not stated & 22.7 & 3.9 & 3.4 & 13.8 \\
& & & & \\
Total & 100 & 100 & 100 & 100 \\
N (000s) & & & & \\
\hline
\end{tabular}

was only 2.9 (see Table 13). The occupational structure changes were larger for women than for men. For example, for Jabotabek, the index of dissimilarity of occupational distribution of women between 1980 and 1990 is 11.0, the comparative figure for men is 7.6.

As in Jakarta, the index of dissimilarity for Bangkok shown in Table 13 was higher in the inner ring than in the core, though the contrast between the two was not as sharp as for Jakarta. However, in Bangkok, the index of dissimilarity for the outer ring was lowest of all, reflecting no doubt the considerable distance of many parts of the outer ring from Bangkok and the consequent more limited effect of metropolitan growth on its employment structure.

The changes in Taipei's occupational structure, no less so than the trends in its industrial structure, are different from those of the cities in the SE Asian countries. While Jabotabek experienced growth in the number of production related workers between 1980 and 1990, 
Taipei has actually experienced a net decline in workers in that category during the same period. Taipei's employment growth has been most significant in the clerical workers

category. Also, it was in the outer ring rather than the inner ring that there were major shifts in the occupational structures between the two census periods. What could be the explanation for these different patterns in Taipei EMR? First the patterns reinforce the previous observation about the emergence of a post-industrial economy in Taipei, with the shift from secondary to tertiary activities. Secondly, the larger shifts in occupational structure of the outer ring appear to mean that in Taipei, it is the outer ring which is going

through major economic transformation, as the inner ring had already gone through such changes earlier. Taipei's outer rim growth is indicative of the phenomena which are likely to be emerging in the cities in SE Asia in the future.

Table 13: Index of Dissimilarity (ID) between Occupational Structures by Sex in 1980 and 1990

(Indicator for changes in occupational structures for men and women in all zones)

\begin{tabular}{lcccc}
\hline EMR & $\begin{array}{l}\text { ID in Core } \\
\text { between 1980 } \\
\text { and 1990 }\end{array}$ & $\begin{array}{l}\text { ID in Inner } \\
\text { Ring Between } \\
\text { 1980 and 1990 }\end{array}$ & $\begin{array}{l}\text { ID in Outer } \\
\text { Ring Between } \\
1980 \text { and 1990 }\end{array}$ & $\begin{array}{l}\text { ID in EMR } \\
\text { between 1980 } \\
\text { and 1990 }\end{array}$ \\
\hline Taipei (Total) & 11.4 & 9.5 & 10.6 & 10.3 \\
Male & 10.6 & 6.9 & 7.8 & 8.1 \\
Female & 9.3 & 11.9 & 15.7 & 11.2 \\
Jabotabek (Total) & 2.9 & 19.5 & 9.6 & 7.7 \\
Male & 2.9 & 18.8 & 9.2 & 7.6 \\
Female & 8.0 & 28.3 & 12.2 & 11.0 \\
Bangkok EMR & 8.9 & 12.6 & 5.1 & 8.0 \\
Male & 9.4 & 12.2 & 25.1 & 10.2 \\
Female & 9.0 & 13.0 & 6.3 & 9.3 \\
\hline
\end{tabular}

Analysis of the data on occupational structure by sex for 1980 and 1990 shows that occupational structure changes are again larger for women than that for men, a similar finding to that from cities in SE Asia. However there are also some distinct differences, particularly with respect to changes in the occupational structures in the different zones. Whereas in Jabotabek, 
changes in the occupational structure of both men and women were largest in the inner ring, in Taipei EMR the change in the occupational structure was largest in the outer ring for women (ID $=10.7)$ and largest in the core area for men (ID = 10.9). For women in the outer ring, there has been a major growth in employment of clerical workers (from 15 percent to 28 percent share of total employment) and service workers (from 8 percent to 13 percent). Likewise for men in the core area, the greatest growth in employment was in the clerical category (from 20 percent to 27 percent share of total employment) and traders and sales categories (from 17 percent to 22 percent).

\section{OCCUPATIONAL STRUCTURE DIFFERENCES BETWEEN ZONES}

In all the extended metropolitan regions, one common finding, not surprisingly, is that occupational structures of the core are generally more similar to those of the inner ring than to those of the outer ring - that is, dissimilarity from the core increases with greater distance from the core (Table 14). More interestingly, in Bangkok, Manila and Taipei, employment structure of the inner ring resembled that of the outer ring more than it resembled that of the core, but in Jakarta the inner ring resembled the core more than it did the outer ring. This suggests a more thoroughgoing transformation of the employment structure of the inner ring in the case of Jakarta.

Table 14: Index of Dissimilarity Between Occupational Structures of Core, Inner Ring and Outer Ring, 1990

\begin{tabular}{lccc}
\hline EMR & $\begin{array}{l}\text { Index of Dissimilarity } \\
\text { between Core and } \\
\text { Inner Ring }\end{array}$ & $\begin{array}{l}\text { Index of Dissimilarity } \\
\text { Between Core and } \\
\text { Outer Ring }\end{array}$ & $\begin{array}{l}\text { Index of Dissimilarity } \\
\text { between Inner Ring } \\
\text { and Outer Ring }\end{array}$ \\
\hline Taipei & 24.7 & 43.7 & 19.1 \\
Jabotabek & 14.1 & 28.0 & 19.3 \\
Bangkok EMR & 29.2 & 38.9 & 15.5 \\
Manila EMR & 24.4 & 31.8 & 17.6 \\
\hline
\end{tabular}


Comparison of index of dissimilarity between occupational structures of different zones in Jabotabek for 1980 and 1990 indicates an important trend towards narrowing of differences in occupational structures between zones over time (See Table 15). The index of dissimilarity between zones in 1990 are lower between all zones than the corresponding figures for 1980. But the greatest change in index of dissimilarity was between DKI and inner ring - a reduction from 22.3 to 14.1 between 1980 and 1990 whereas the index of dissimilarity between inner ring and outer ring changed from 24.7 to 19.3 during the same period. However, the index of dissimilarity between occupational structures of DKI and outer ring changed only from 29.5 to 28.0 within the intercensal period, reflecting only a modest change in the two zones compared to change in the inner ring.

Table 15: Index of Dissimilarity between Occupational Structures in Different Zones in Jabotabek, 1980 and 1990

\begin{tabular}{llll}
\hline Year & $\begin{array}{l}\text { Index of Dissimilarity } \\
\text { between DKI and Inner } \\
\text { Ring }\end{array}$ & $\begin{array}{l}\text { Index of Dissimilarity } \\
\text { between DKI and Outer } \\
\text { Ring }\end{array}$ & $\begin{array}{l}\text { Index of Dissimilarity } \\
\text { between Inner Ring and } \\
\text { Outer Ring }\end{array}$ \\
\hline 1980 & 22.3 & 29.5 & 24.7 \\
1990 & 14.1 & 28.0 & 19.3 \\
\hline
\end{tabular}

(Note: Calculations based on occupational structures in different zones within Jabotabek in 1980 and 1990)

\section{OCCUPATIONAL SEGREGATION BY SEX, 1990}

The index of dissimilarity has again been used to examine the extent of occupational segregation by sex in each of the zones in the EMRs. The analysis of the occupational structures of both male and female populations in each zone of the EMRs indicates that in Jabotabek and Bangkok EMRs, occupational differences by sex are largest in 
Table 16. Index of Occupational Segregation by Sex in the Three Zones of EMRs

\begin{tabular}{lclcc}
\hline EMRs & $\begin{array}{l}\text { ID between } \\
\text { Male and } \\
\text { Female Pop. in } \\
\text { Core }\end{array}$ & $\begin{array}{l}\text { ID between } \\
\text { Male and } \\
\text { Female Pop. in } \\
\text { Inner Ring }\end{array}$ & $\begin{array}{l}\text { ID between } \\
\text { Male and } \\
\text { Female Pop. in } \\
\text { Outer Ring }\end{array}$ & $\begin{array}{l}\text { ID between } \\
\text { Male and } \\
\text { Female Pop. in } \\
\text { EMR }\end{array}$ \\
\hline Taipei EMR & 22.2 & 20.9 & 22.2 & 22.4 \\
Japotabek & 25.8 & 18.2 & 11.7 & 21.2 \\
Bangkok EMR & 22.1 & 14.4 & 13.2 & 17.1 \\
Manila EMR & 27.9 & 32.6 & 42.4 & 27.2 \\
\hline
\end{tabular}

the core areas and least in the outer rings (Table 16). This may be explained by the fact that in the outer rings, with dominance of agriculture, there is not much scope for occupational differences by sex, but with increased specialization of work in the core area, there are sharper differences in occupations between sexes. It is interesting to note that there are similar levels of segregation in Taipei EMR in all three zones, indicating that location is not an important factor for segregation by sex in Taiwan. In the case of the Philippines, the opposite trend of higher index of dissimilarity between male and female populations in the outer ring is explained by the fact that in the Philippine census, men have been largely recorded in agricultural occupations while women have much more frequently been left out of the economically active population by being included - probably incorrectly, in many cases - in the non-gainful occupations.

\section{EMPLOYMENT PATTERNS OF MIGRANTS AND NON-MIGRANTS}

Migrants to the extended metropolitan region tend to be over- and under-concentrated in different occupations, and these concentrations are also different in different zones of settlement and for migrants from different source areas. Although there is not space here to elaborate in detail, it is clear from 1980 data (not shown) that in the case of the Bangkok EMR, workers born in Bangkok itself or outside the EMR were much more strongly represented in 


\section{JONES, TSAY AND BAJRACHARYA}

professional, administrative and clerical occupations than were those who were born elsewhere in the extended EMR, over 40 per cent of whom were still employed in agriculture, and a disproportionate number of the rest in the transport and craftsmen groups of occupations, indicating overrepresentation in industrial employment. Migrants moving into the inner zone tend to have much higher levels of education than the local-born within this zone, as was also found in Jakarta, and this largely accounts for the different occupational patterns.

In Jakarta, migration patterns from different regions are certainly not gender-neutral. A substantially higher proportion of working females are migrants from Central and East Java than is the case with working males. This appears to indicate strong patterns of female migration to Jakarta from Central and East Java, but it could also reflect, in part, higher labour force participation among female migrants from Central and East Java than among migrants from elsewhere or among the long-time Jakarta residents (Jones and Mamas, 1996: 63).

Migrants in Taiwan are highly selective in terms of educational attainment, especially those moving to Taipei City. As a result, the stock of human capital of Taipei has increased substantially in the process of population redistribution. In the surrounding (Taipei) prefecture, however, the low educational selectivity of migrants has brought only limited improvement in its quality of human resources. In terms of employment patterns, migrants to Taipei City in general were disproportionately in the service sector compared to the City's native-born. At the same time, Taipei City received more single female migrants than their male counterparts. As a response to the economic transformation, migration had a significant effect on the population composition and played an important role in the changing employment pattern of Taipei City as well as its outer zone (Lin 1998).

Data (not presented) on occupational structure of employment by sex compiled from the 1990 Taiwanese census show that inmigrants to the Taipei EMR tend to be overrepresented in some occupations and under-represented in others. For example, regardless of sex and zone of the extended area, migrants had an above-average share in professional occupations, because of the high degree of positive selection in education. 
In the core and the inner ring of the Taipei EMR, the occupational structure of migrants closely resembles that of non-migrants. Both groups were mostly represented in the three categories of (a) professional, (b) administrative, clerical, sales and services, and (c) blue collar occupations. In the outer ring, migrants were well represented in professional, administrative/clerical and blue collar occupations, but non-migrants apparently concentrated more in the middle and lower level occupations (administrative/clerical, agricultural, and blue collar types). These findings suggest that zonal characteristics of the Taipei EMR have less effect on the occupational structure of migrants than that of non-migrants.

\section{CONCLUSIONS}

Analysis of demographic and employment change in the complex entities represented by extended metropolitan regions requires some form of areal disaggregation. A relatively simple, yet meaningful approach is to define a core, an inner zone and an outer zone. The findings of this paper indicate that such zones differ significantly in their demographic and employment characteristics, and in the dynamics of change in these variables. The inner ring tends to be the zone of greatest change, though this depends on how widely or narrowly the boundaries of the inner ring are drawn. In Taipei, where they are drawn more narrowly, the outer zone also displays considerable employment change. In Bangkok and Jakarta, where they are drawn more widely, the inner zone encompasses the most dynamic change. Over the course of the 1980s, the employment structure of the inner ring in Jakarta came to resemble that of the core (D.K.I. Jakarta) much more than it had at the beginning of the period.

If a zonal approach is to be used in analysis of extended metropolitan regions, a degree of consensus about the appropriate boundaries to use for these zones is crucial, so that national statistical agencies can be pressured to produce data for these zones. Without such data, severe constraints are placed on analysis of trends on a zonal basis. 
Not surprisingly, employment change in the large extended metropolitan regions studied in this paper is characterized by a rapidly declining share of agricultural employment in the core and the inner ring, offset by a rising share of manufacturing employment and of a range of other employment which differs across the different EMRs. The share of females in total employment is rising in all EMRs studied. This is not surprising, in view of the rising labour force participation rates for females quite generally throughout East and Southeast Asia. But the EMRs tend to be at the "cutting edge" of such employment change, being the locus of much of the higher-status employment for women.

Migration plays an important role in the changing employment structure of both the core and of the inner ring. Because migrants are disproportionately concentrated at the young ages they tend to play an important role in filling emerging employment niches. In the inner ring, two quite different patterns of migration are operating, one stemming from the suburbanization of the metropolitan population, and the other a more youthful inflow from other parts of the country. The employment implications of these two different flows are very different. The sex composition of migration flows from different areas also differs considerably, at least in the case of Jakarta. In part, this may reflect adaptation to the very different pattern of employment opportunities for men and women, but as well, historical patterns of work-oriented migration from different areas.

Though the analysis of change in EMRs is assisted by the kind of analysis conducted in this paper, the approach still has many limitations. For example, interaction between the zones is intense, and could be better analyzed through traffic flow data, and analysis of daytime and nighttime populations of the zones, than through the comparative statics of employment change studied here. Nevertheless, we believe that we have demonstrated the value of using the concept of zones as a tool for more effective understanding of population and employment dynamics in mega-urban regions. 


\section{APPENDIX \\ CRITERIA FOR SELECTING ZONES}

\section{CORE}

For all three cities - we use the core metropolitan area as defined in recent years:

DKI Jakarta 664 sq. km.

Bangkok Metropolitan Administration (BMA) 1565 sq. km.

Metro Manila $636 \mathrm{sq} . \mathrm{km}$.

\section{EXTENDED METROPOLITAN REGION}

Jakarta - Jabotabek (i.e. DKI Jakarta plus kotamadya Bogor and kabupaten Bogor, Tangerang and Bekasi). This is a well accepted region for national planning purposes.

Bangkok - the extended Bangkok Metropolitan Region (BMR), used in most recent National Urban Development Policy Framework for the 7th Plan (1992-1996). In addition to the BMA, this includes the changwats of Samut Prakan, Pathum Thani, Samut Sakhon, Nakhon Pathom, Nonthaburi, Ayuthaya, Saraburi, Chachoengsao, Chonburi and Rayong.

Manila - Metro Manila plus all surrounding provinces of which sections are included in the 'inner ring'; i.e. Pampanga, Bulacan, Rizal, Laguna, Cavite and Batangas.

\section{INNER RING}

Jakarta - contiguous densely populated and rapidly growing regions outside the DKI, within the kabupaten of Bogor, Tangerang and Bekasi, plus the kotamadya of Bogor.

Bangkok - the 5 changwats which, when added to Bangkok, officially define the BMR; i.e. Samut Prakan, Pathum Thani, Samut Sakhon, Nakhon Pathom and Nonthaburi.

Manila - contiguous densely populated areas outside Metro Manila. Main criterion is population density $>750$ per sq. $\mathrm{km}$. in 1990 . But a few small exceptions to this criterion were allowed (e.g. to include all of Antipolo in Rizal). 
38 JONES, TSAY AND BAJRACHARYA

FIGURE 1: BANGKOK EXTENDED METROPOLITAN REGION

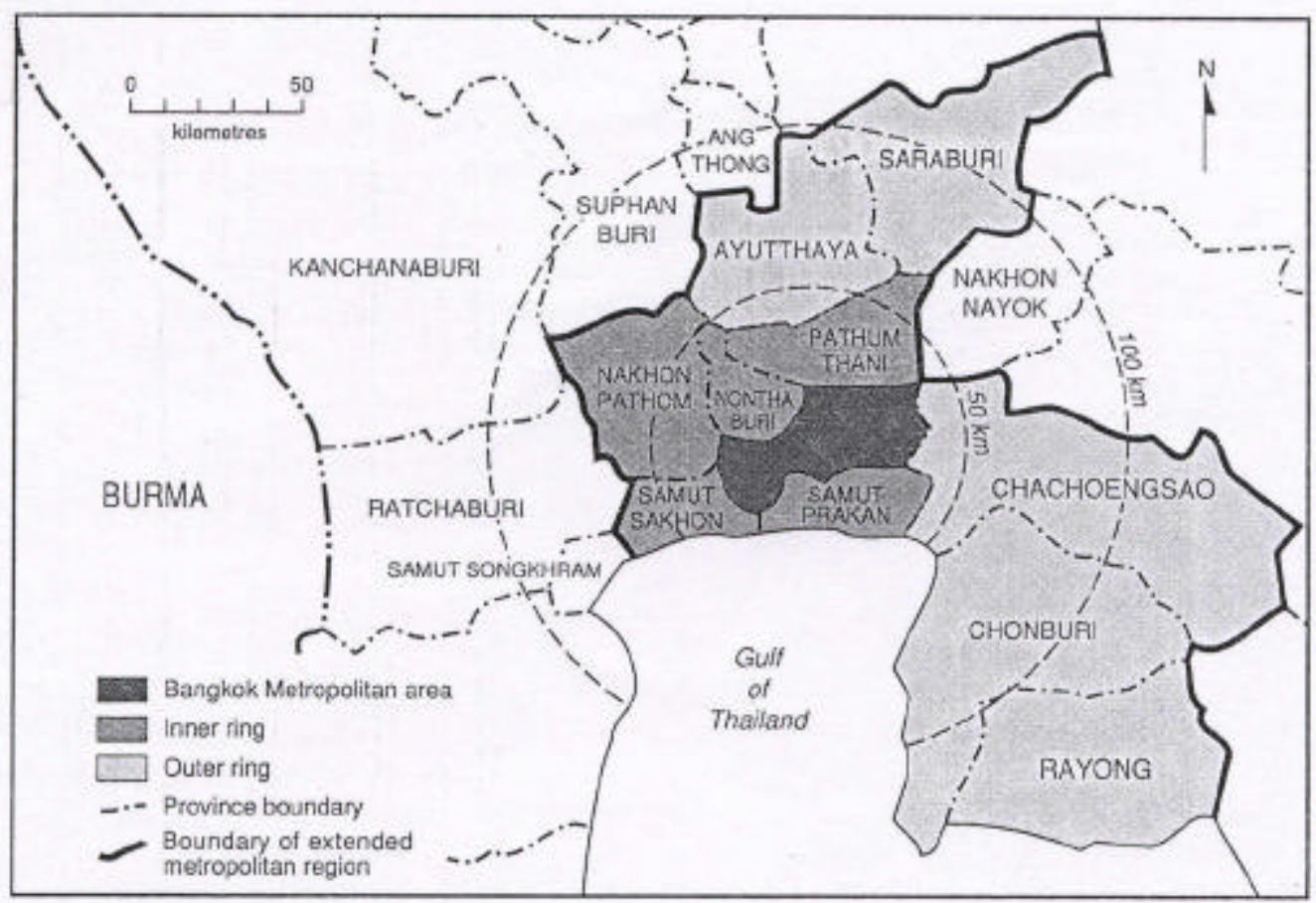


FIGURE 2: JAKARTA EXTENDED METROPOLITAN REGION

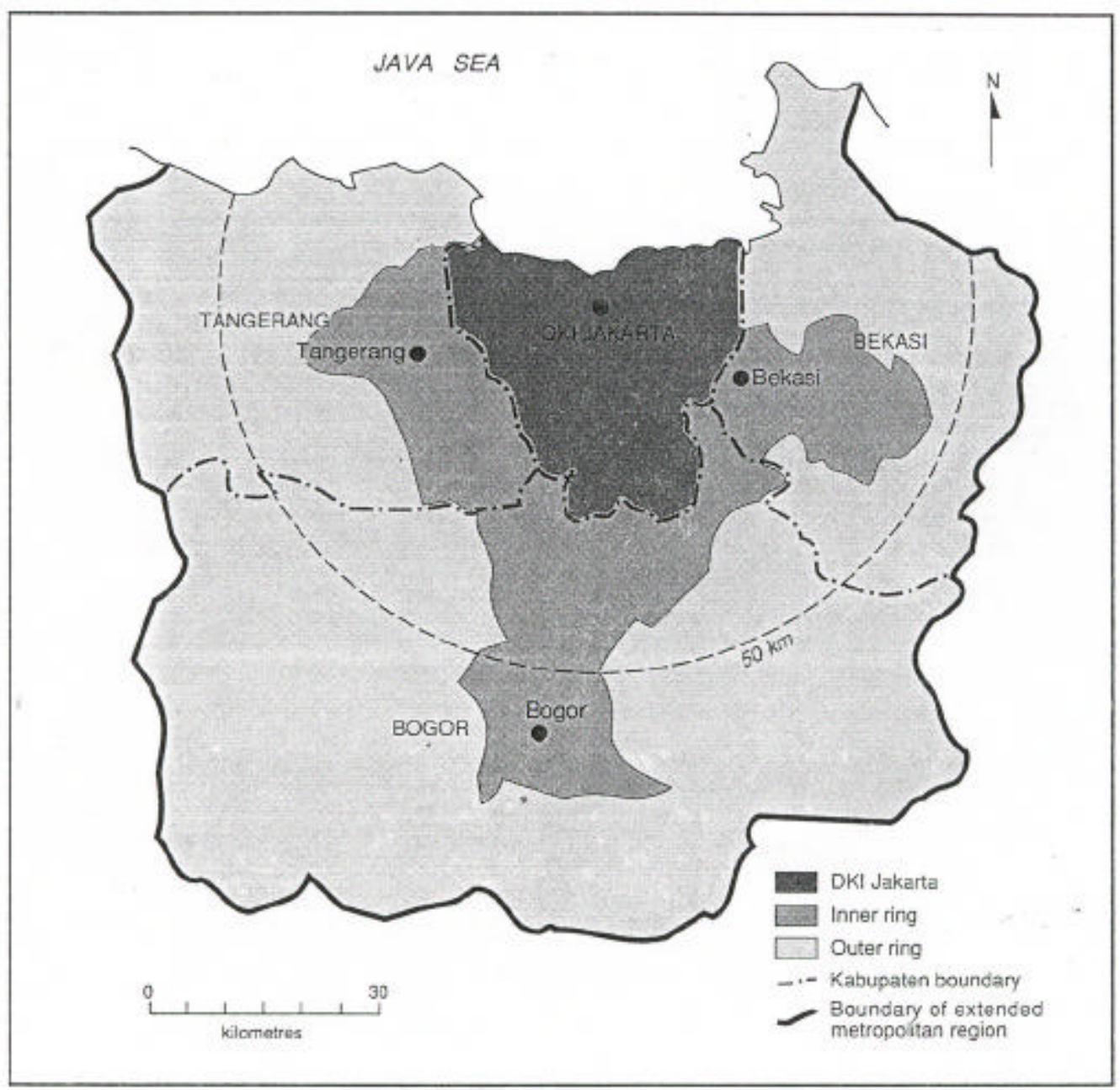


40 JONES, TSAY AND BAJRACHARYA

FIGURE 3: MANILA EXTENDED METROPOLITAN REGION

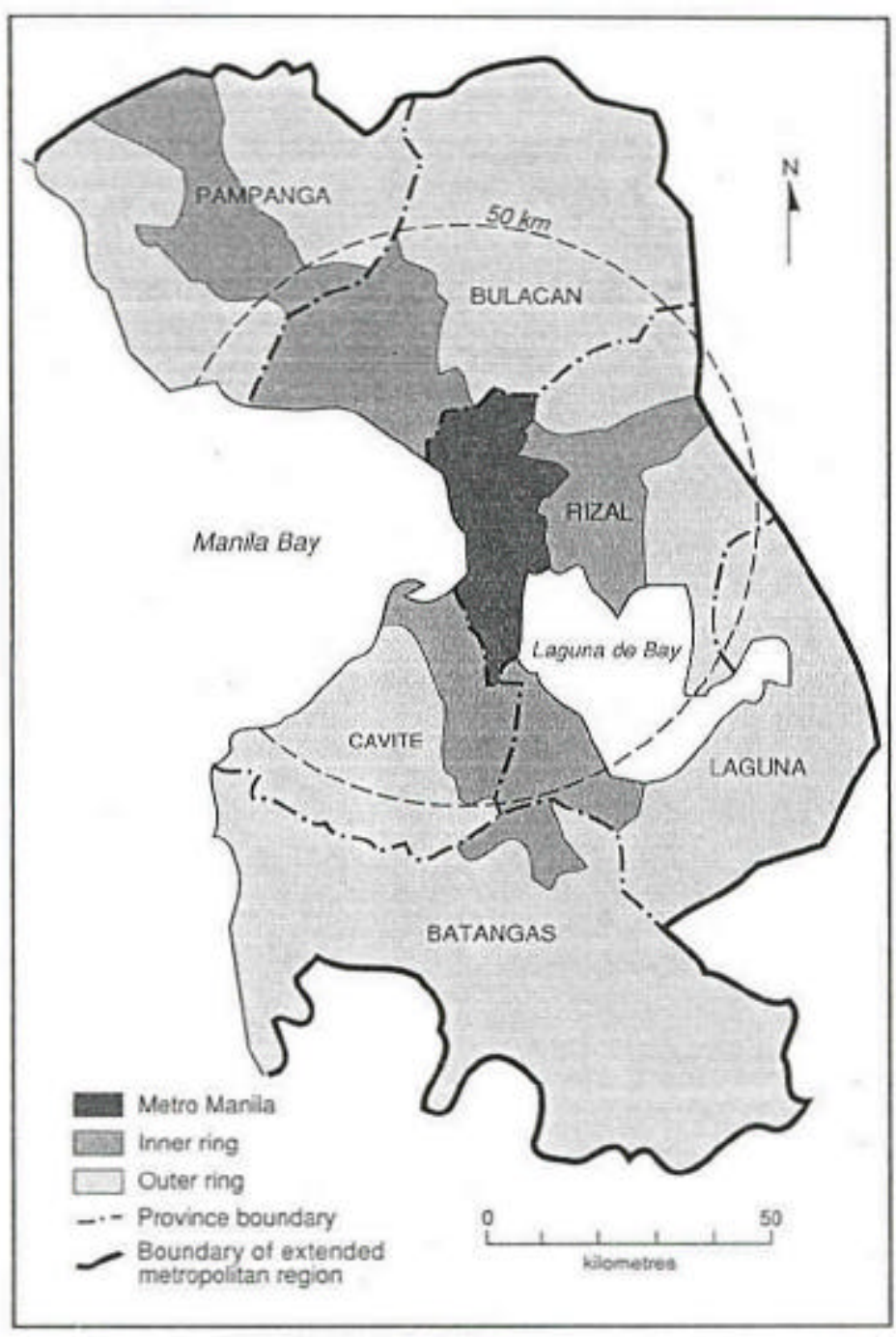


FIGURE 4: TAIPEI EXTENDED METROPOLITAN REGION

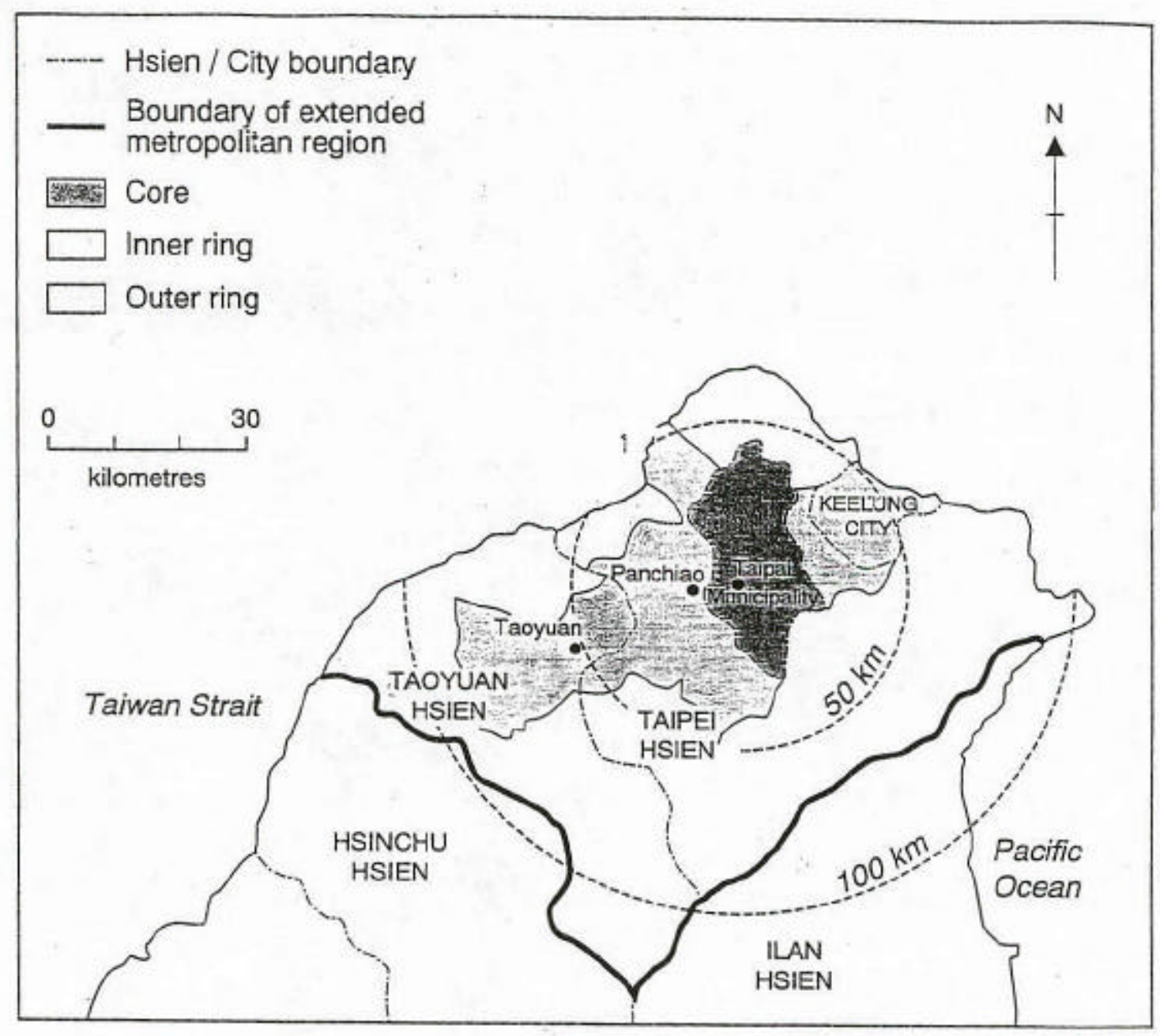




\section{REFERENCES}

Champion, A.G. (ed), 1989, Counterurbanization: The Changing Pace and Nature of Population Deconcentration, London: Edward Arnold.

Firman, Tommy, 1992, "The spatial pattern of urban population growth in Java, 1980-1990", Bulletin of Indonesian Economic Studies, 28(2): 95-109.

Frey, William H. and Alden Speare Jr., 1992, "The revival of metropolitan population growth in the United States: an assessment of findings from the 1990 Census", Population and Development Review, 18(1).

Fuguitt, G.V., 1985, "The Nonmetropolitan Population Turnaround" Annual Review of Sociology, 11, 259-280.

Fuguitt, G.V. and D.L. Brown, 1990, "Residential Preferences and Population Redistribution: 1972-1988", Demography, 27(4): 589-600.

Ginsburg, Norton, Bruce Koppel and T.G. McGee (eds), 1991, The Extended Metropolis: Settlement Transition in Asia, Honolulu: University of Hawaii Press.

Hugo, Graeme J. and Peter J. Smailes, 1985, “Urban-Rural Migration in Australia: a Process View of the Turnaround", Journal of Rural Studies, 1(1): 11-30.

Hugo, Graeme J., 1993, 'Migrant Women in Developing Countries' in United Nations Department for Economic and Social Information and Policy Analysis, Internal Migration of Women in Developing Countries, New York.

Inoue, Shunichi, 1980, 'Stagnant growth of Japanese major metropolitan regions in the era of post-industrial development', in Peter A Morrison (ed), Population Movements: Their Forms and Functions in Urbanization and Development, Liege: Ordina Editions.

Jones, Gavin W., 1984a, 'Links between urbanization and sectoral shifts in employment in Java', Bulletin of Indonesian Economic Studies, 20(3). 
1984b, Women in the Urban and Industrial Workforce: Southeast and East Asia, Monograph No. 33, Development Studies Centre, Australian National University, Canberra.

and Si Gde Made Mamas, 1996, "The changing employment structure of the extended Jakarta metropolitan region", Bulletin of Indonesian Economic Studies, 32( 1): $51-70$.

Lin, Ji-Ping, 1998, Labor Migration in Taiwan, doctoral dissertation, School of Geography and Geology, McMaster University, Ontario, Canada.

McGee, T.G. and Charles Greenberg, 1992, "The emergence of Extended Metropolitan Regions in ASEAN", ASEAN Economic Bulletin, 9(1): 22-44.

NESDB/UNDP/TDRI, no date (c. 1992), National Urban Development Policy Framework, Final Report, Volume 1, Bangkok: National Economic and Social Development Board.

Singarimbun, Nima, 1997, "Changing female labour force participation in Jakarta, with reference to 1980-90”, unpublished PhD dissertation, Demography Program, Australian National University.

Tsuya, Noriko O. and Toshio Kuroda, 1989, 'Japan: the slowing of urbanization and metropolitan concentration', Tokyo: Nupri Reprint Series No 33, Nihon University Population Research Institute.

Vining, D.R. and T. Kontuly, 1978, 'Population dispersal from major metropolitan regions: an international comparison', International Regional Science Review, 3, 49-73.

Vining, Daniel R., 1986, "Population redistribution towards core areas of less developed countries, 1950-1980", International Regional Science Review, 10(1). 